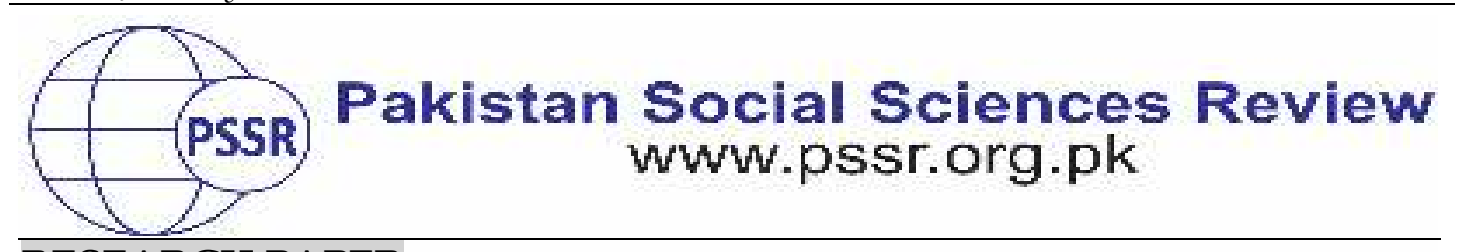

RESEARCH PAPER

\title{
Azerbaijan-Iran Tension: Implications for Pakistan
}

\author{
Dr. Karim Haider Syed ${ }^{* 1}$ Dr. Imran Khan ${ }^{2}$
}

1. Assistant Professor, Pakistan Study Centre, University of the Punjab, Lahore, Punjab, Pakistan

2. Lecturer, Department of Political Science, Government Graduate College, Hafizabad, Punjab, Pakistan

\begin{tabular}{|c|c|}
\hline DU1 & / do \\
\hline INFO & RACT \\
\hline $\begin{array}{l}14,2021 \\
\mathrm{~d}: \\
15,2022 \\
20,2022\end{array}$ & $\begin{array}{l}\text { in } A \\
\text { in } r \\
\text { Aze }\end{array}$ \\
\hline $\begin{array}{l}\text { baijan, } \\
\text { asus region, } \\
\text { olitics, } \\
\text { tan, }\end{array}$ & $\begin{array}{l}\text { within Azerbaijan to secure its interests which were } \\
\text { offensively by Azerbaijan and resulted in conflictin } \\
\text { Later on Azerbaijan held military drill and des } \\
\text { objections, troops from Pakistan, Azerbaijan, and Tur } \\
\text { this drills near Azerbaijan's capital Baku in Septemk } \\
\text { response Iran bring its forces on the Azerbaijan's }\end{array}$ \\
\hline ading & $\begin{array}{l}\text { Ats are } \\
\text { olitical } \\
\text { a close } \\
\text { tegy to }\end{array}$ \\
\hline
\end{tabular}

\section{Introduction}

The holding of the military drill by Turkey, Azerbaijan, and Pakistan in Azerbaijan, as well as the Caspian Sea in September 2021, is the source of newly emerged geopolitics that led to mutual and deep despondency. The tension in the relations between Azerbaijan and Iran have not only abated but is actually rising that has become a phenomenon for the research scholars interested in the geopolitics of the Caucasus region. All new developments in Caucasus region do not, however, imply that Iran is prepared to invade Azerbaijan. Because there is a military Pact between Azerbaijan and Turkey that is signed in June 2021. The member countries became strong military partners after both has signed the Shusha Declaration that forced turkey and Azerbaijan to act jointly, in case of an attack on either member. The parties agreed to work together in the event of military danger, according to the 
treaty (Shahbazov, 2021). Azerbaijan has controlled the areas of Nagorno Karabakh from where a trade route connects Armenia with Iran. After taking control of the key route Azerbaijan halted the trade between Armenia and Iran and started to tax the Iranian trucks and capture them in case of refusal to pay it (Isayev \& Mejlumyan, 2021). Pakistan and Turkey played a key role in the victory of Azerbaijan over Armenia and the Armenian prime minister blamed the military presence of Pakistan in Nagorno Karabakh during its war with Azerbaijan (Khan \& Haider, 2021). After the end of the war, Azerbaijan thanked Pakistan and Turkey for their support for Azerbaijan, and the people of Azerbaijan thanks for raising Pakistani flags in the region. Meanwhile, Pakistan and Turkey were invited by Azerbaijan for a joint military drill in Baku that lasted for two weeks despite the objection of Iran. This study explains the newly developed geopolitics in the Caucasus region after the victory of Azerbaijan in the Nagorno-Karabakh region against Armenia with the help of Pakistan and Turkey. Iran trade with Armenia, Russia, and beyond had a route through the Nagorno-Karabakh region that was previously under the control of Armenia. The military presence of Pakistan, Turkey, and the presence of Israeli personals on the bordering region of Iran created a sense of apprehension and resulted in a counter-strategy of Iran.

Hypothesis; Pakistan's new engagements in the Caucasus region have a negative impact on its relations with Iran but could lead to open new horizons of economic and security cooperation. (Lindenstrauss \&Celniker, 2012), examined the key reasons of tensions between Azerbaijan and Iran in 2012. Because in that years both had called back their ambassadors were for "consultations" after attempted Iranian terrorist attacks on Azerbaijani territory. Detentions of citizens for compelling reasons, and an increase of Iranian naval presence in the Caspian Sea were few of the indications of that antagonism. The authors had examined the emergence of antagonism from both short and long- term perspectives. They found that since Azerbaijan's independence in 1991, relationship between the two nations had been tight, so any squabble was unsurprising. At the same time, this strain, which is unique in comparison to prior years, might be described by the strengthening of the economy and Azerbaijan invitation of other nations like, Pakistan, Turkey and Israel on its soil.

\section{Findings}

The "Three Brothers Drill" resulted in sharp changes in the geopolitics of the Caucasus region as during this military exercise in September 2021 Iran could not conceal its displeasure and sent its discontent through its proxies and later on directly. The first comment to the tripartite exercise in Azerbaijan was from Syed Hassan Ameli during the Friday prayer sermon. He is the religious leader of Iran's delegation in the Ardabil area of Azerbaijan and is considered as a representative of Khamenei the supreme leader of Iran in Azerbaijan. Syed Hassan Ameli cautioned Azerbaijan not to mess with a lion's tail and urged the Islamic Revolutionary Guard 
of Iran to demonstrate its might in Azerbaijan. The phrases of Ardabil Friday prayers prompted Azerbaijan and Iran to threaten each other (Rad, 2021). On the call of Syed Hassan Ameli Iran started its own military drill near its frontier with Azerbaijan. The Islamic Revolutionary Guard Corps' Sarollah Division has a huge deployment on the northwest frontier. Baku fired at an Iranian chopper during the drill. Iranians on social media demanded the hashtag "Death to Baku" in response to their requests for a swift reaction.

Elman Mammadov, an Azerbaijani parliamentarian, responded to the Ameli warning to Azerbaijan to not play with the lion tail and said that if Iran had a tail, Azerbaijan would chop it off. On the statement of Elman Mammadov, Iran's representative in the Islamic Consultative Assembly, Ahmad Naderi said that Iran's patience demonstrated its greatness and that friendly neighboring countries were obligated to follow good neighborly values. Azerbaijan has also positioned antiaircraft infrastructures near its capital, which is unsurprising given that Mohammad Bagheri, Iran's chief of staff, has indicated that if the battle began, "the IRGC will strike Azerbaijan with 4,000 missiles, which will totally destroy it." Furthermore, the leader of the IRGC forces in Tabriz Col. Hossein Pursmail, stated that "repeating Israel's warnings against Iran through the mouth of Baku is not only not in Azerbaijan's interests, but is also a threat to its's own survival, that is why Iran has limited options (Mikovic, 2021). In response to the IRGC exercises, Sardar Jalaloglu, the leader of the Democratic Party of Azerbaijan, claimed, "As soon as Iran strikes against us, Pakistani forces will be in Tehran." "Iran must not engage in such behavior!" this statement bring Pakistan to the headlines. The history of Pakistan and Iran's relations remained quite different in the past. Statement of Sardar Jalal Oglu indicated the new geopolitical dimensions of Pakistan's approach towards the caucus region and its relationship with Iran and Azerbaijan. Iranian drills in September 2021 appear to be sending a clearer message, and they've been backed by a storm of triumphalist broadsword from Iran (Club, 2021).

Hossein Dalirian, a commentator linked with the Iranian military tweeted on September 30, 2021: "Imagine a battle with Azerbaijan. He further boasted that Iran had the ability to launch 1,000 ballistic missiles and hit 1,000 targets in Azerbaijan. He claimed that the conflict would be over in a single day and Azerbaijan would be no time to use any other tools (Dalirian, 2021). In response to his comment, an Azerbaijani said "Pay no attention to boasting". President Ilham Aliyev of Azerbaijan expressed his displeasure with the beginning of the Iranian military drill on September 27, 2021. He exclaimed with wonder that any military drill could be conducted on the territory of any country as it was their right to do so. But why did Iran choose to time when Azerbaijan is hosting a triparty drill, and why on its border? (Sofuoglu , 2021). Azerbaijan arrested a pro-Iranian preacher and shut down an Iranbased website in Azerbaijan and also a Masjid. Aliyev explained that that was the first moment Iran had organized such a display of force so near to Azerbaijan's 
frontier since the collapse of the Soviet Union. He on October 15, 2021, has enraged Iran once more when he stated that Azerbaijan had stopped a drug trafficking route from Iran through [the] Jabrayil province of Azerbaijan to Armenia and further to Europe. He said this at the summit of the Commonwealth of Independent States (CIS), (aliyev, 2021). He was responded by Mahmoud Abbaszadeh a spokesperson of the parliamentary committee of Iran and Ali Shamkahni who is secretary of the supreme national security council of Iran by stating that Azerbaijan's president had ignored the customs and requirements of the neighborhood and he had made false and negative statements that were not a sign of good faith and farsightedness (Sinaee, 2021).

\section{Israel Factor}

Saeed Khatibzada the Foreign Ministry spokesman of Iran said Military drills in the Iran region's northwestern border regions were a concern of Iranian sovereign rights and Iran would take all reasonable steps for its national defense. He also said without naming Israel that Iran would not accommodate the presence of a Jewish régime close to its frontier. Kioumars Heydari the commander of Iranian land forces stated that Iranian sensitivity to its border with Azerbaijan had intensified since the new regime of Naftali, and Israeli operations there were fully under Iranians' observation ("Iran says military exercises near Azeri border an issue of 'sovereignty'", 2021). On September 29, 2021, Brigadier General Mohammad Pakpour commander on IRGC of Iran said that Iran would not allow its neighbors to become a sanctuary and a base for the being there Iran's anti-security actions of the Israeli regime that is a fake regime ("No Place for Israel in Iran's Neighboring Countries: IRGC General Politics news", 2021). He further said that there was no doubt that the Israeli regime helped and supported the definite regional states with the resolve of constructing divergences and rift among Muslim countries and Azerbaijan and other regional players were aware more than anybody else of the motives for the war games of Iran. It is a matter of fact that Azerbaijan and Israel had long relations in the field of defense but they become visible in the Nagorno-Karabakh conflict. On September 30, 2021, Hussain Amir-Abdollahian warned Azerbaijan during his meeting with the Azerbaijan ambassador to Iran that Iran would not stomach the existence and movement of the Zionist government on its borders that threatened its national security ("Amirabdollahian: Iran does not tolerate Zionist regime's presence near its borders", 2021). In case of direct or indict confrontation between Iran and Azerbaijan in which Israel would be a factor, what will be the position of Pakistan is the question.

\section{Turkey Factor}

There are fears among foreign policy experts of Iran that the Turkey and Azerbaijan nexus is attempting to surround Iran and sow instability among the Azeri ethnic minority of Iran. Iran was irritated by Turkey's apparent obliviousness to their concerns. Recep Tayyip Erdogan in December 2020, recited a poem in which he was 
lamenting the divide of Azeris along the Aras River and indirectly supported panTurkism, which caused a furious protest in Iran. Ali Shamkhani the Secretary Supreme National Security Council of Iran slammed recent remarks of the President of Turkey that Iran would not risk a confrontation with Azerbaijan because of its own Azeri population. Kioumars Heydari the commander of Iranian land forces expressed concern over the presence of some Syrian armed groups that was an apparent reference to make claims that Turkey was busy in the recruitment of Islamists to go and fight in Syria against the pro-Iran Asad regime. Heydari said Iran was unsure if the fighters had left the region (Esfandiari, 2021) Turkey is concerned about the strengthening of Iran-Armenia ties. The Turkish president has explained that the Azerbaijani influence within Iran, was the reason why Iran could not sustain its adversarial attitude toward Azerbaijan. He said that by targeting Azerbaijan, Iran could not offend and humiliate its own large Azerbaijani community. Any escalation between Iran and Turkey also has consequences for Pakistan and Iran is a neighboring state and Pakistan has developed a close relationship with turkey. Pakistan must have to think about the situation of confrontation between Turkey and Iran.

\section{Iran Trade Route through Armenia}

In September last year, Azerbaijan and Armenia fought a war over the disputed Nagorno-Karabakh region. About 6,000 lives were lost in the six-week war, and Azerbaijan occupied a large area of Karabakh. Now that the region has been annexed by Azerbaijan, Iran's trade routes have been severely affected. In the war between Azerbaijan and Armenia, Iran was quietly supporting Armenia, while Azerbaijan, like Iran, is a Shiite-majority country. Iran has access to West Asia and Russia via the Karabakh trade route but is now under Azerbaijan's control (Oxford Analytica (2021). Azerbaijan arrested Iranian truck drivers for not transit fee that escalated the tension in the region. The complex ethnic make-up, the abundance of energy resources, and an intersection of expanding global trade routes mean the scramble to hold sway in the Caucasus will continue. As long as Karabakh was under Armenian occupation, Iran used to send goods to the Middle East and Russia by truck and other means of transport without paying customs. During the war, Azerbaijan has taken control of the Karabakh region, which has cut off Iran's entry into West Asia and that it is receiving money from Iran to reach Armenia.

The recent enmity between Azerbaijan and Iran has had a number of ramifications, included forcing Iran to explore alternate transit routes to Armenia, Georgia, and Russia. The option by Azerbaijan to impose limitations on Iran's cargo traveling through the Goris-Kapan highway, a key section of the primary land route connecting northern and southern Armenia, and a segment of a 400-kilometer road infrastructure extending from the Iranian city of Norduz to Yerevan Armenia's capital, was the turning point. Much of this roadway crosses a contested section of 
the Armenian-Azerbaijani border or directly enters the territory of Azerbaijan (Isayev and Mejlumyan, 2021). The explanation of Azerbaijan on its policy seems quite simple for Azerbaijan. It can be said that it is a matter of the sovereignty of Azerbaijan and it can collect taxes for transit from his land. In addition, Azerbaijan is concerned that Iranian trucks could use the route to transport weapons that could fall into the hands of its enemy Armenia.

In addition, there is anger in Iran over the halt of Iranian trucks. Two Iranian truck drivers were detained by Azerbaijan for non-payment of "road tax", after which the Iranian Foreign Ministry demanded their immediate release. The blocking of trucks by Azerbaijan was unacceptable to Iran that threatened its trade security in West Asia. The Tatev-Aghvani route is the first substitute land corridor that completely bypasses the territory of Azerbaijan. It is a matter of fact this route is notorious for its narrow passes and steep slopes that trucks have a problematic time crossing, principally in the snowy and rainy state of affairs. Iran wants to show its seriousness about the road link between Armenia and West Asia through military exercises.

\section{Iran's concerns over the Greater Azerbaijan Issue}

Iran may possibly take a chance and battle Azerbaijan, but millions of Azerbaijanis residing in Iran could back an armed struggle against Iran. The success of Azerbaijan in the war against Armenia instilled a sense of national pride among Azerbaijanis living in Iran, implying that Iran will think long and hard before confronting Azerbaijan. Iran may also be worried about the impact of Azerbaijan's victories and regional relationships on its northern Azeri population. A considerable Azeri population, believed to be the country's largest minority, lives in the area. Most Azerbaijanis call the northern part of Iran South Azerbaijan, home to about 20 million people of Azerbaijani descent. After Azerbaijan's victory in the Nagorno-Karabakh war, against Armenia, Azerbaijani people living in northern Iran organized public celebrations and urged the Iranian government that the Iranian-Armenian border should be closed after the Armenian atrocities against Azerbaijani people in Nagorno Karabakh.

Many Azerbaijani nationalists and intellectuals have called for the unification of the northern and southern parts in the name of cultural and social identity, known as 'Greater Azerbaijan'. All of this worries Iran. In Iranian Azerbaijan, meanwhile, there is now no actual prospect of separatism. This problem was exacerbated when the Turkish-Pakistani-Azerbaijani trio began joint military exercises. The three Brothers' joint military exercise on the Iranian border shows the Azerbaijani people a kind of force against Iran and in response, Iran wants to give a signal to the Azerbaijani community by conducting its own military exercise near the border of Azerbaijan. It is also a signal to the Azerbaijani ethnic community, which has a significant presence in northern Iran. Demonstrations in support of Azerbaijan also 
took place in northern Iran during the Azerbaijani and Armenian wars. Iran is concerned about the same Azerbaijani separatist community and thinks it could increase. That is why the military exercises near the border were a signal to the people of Azerbaijan living in the country. Another important incident happened in the context of Iran- Azerbaijan tension on 23 October 23, 2021, when the new governor of Iran's East Azerbaijan Province was attacked by a person who stormed the platform and smacked him. On October 23, in the city of Tabriz, the new governor, General Abedin Khorram, had barely entered the podium when an anonymous person walked onto the stage and assaulted him without warning ("Iranian Governor Assaulted During Inauguration Ceremony", 2021).

There are social media posts depicting the separatist slogans on walls and boards" South Azerbaijan is not Iran" (Mohamad, 2021). Naftali Bennett the extremist prime minister of Israel make the suggestion that 'by a thousand cuts' Iran should be killed that has clear means for the sovereignty of Iran and he must mean subsequent disintegration of Iran (Harel, 2021) . Hossein Amir-Abdollahian, Iran's foreign minister, later on, tried to normalize the situation and said Iran has the right to conduct drills and emphasized the "significance" of cooperation between Iran and Azerbaijan, which share a 700-kilometer border. After it, Iran's ambassador to Azerbaijan, Abbas Musavi, stated that Iran's military maneuvers were planned ahead of time, were not a "threat" to Azerbaijan.

\section{Three Brothers-2021 Exercise}

Three Brothers military drills were held by Azerbaijan, Turkey, and Pakistan in Azerbaijan from 12 to 23 September 2021. In which Turkey participated that has the second-largest armed force of NATO, and Pakistan participated that is the only Islamic nuclear power. When Pakistan and Turkey in military maneuvers join Azerbaijan, it must bring worries for Iran, and its's military maneuver [reveals] its apprehension. Iran explained its opposition to the "Three Brothers military drill 2021" that includes Pakistan, Turkey, and Azerbaijan by stating that this trilateral drill has violated the provisions of the Convention that was agreed to settle the legal status of the Caspian Sea ("'Three Brothers 2021' Pakistan, Turkey, Azerbaijan joint military drills conclude: Dope Desi", 2021). According to Iran military presence of any state is not allowed in this region other than Azerbaijan, Iran, Armenia, Kazakhstan, and Russia under the protocol of the agreement between these states. So the presence of Pakistani and Turkish troops in Azerbaijan for the military drills was against the spirit of the agreement.

This military drill brought Iran and Azerbaijan stand-off and could also affect the relations between Pakistan and Iran. These drills were seen as a danger to the national security of Iran. Iranians justified its aggressive response by claiming that the arrangements between the five countries surrounding the Caspian Sea dictate that 
any troop presence at any location is unlawful. In response to the "Three Brothers Drill," Iran also started military drills alongside the bordering region of Azerbaijan. Other sensitivities have been a series of military drills including Pakistan, Azerbaijan, and Turkey, as well as an increase in anti-Iranian magniloquence from Azerbaijani leaders. Turkey, Azerbaijan, and Pakistan staged combined military drills in the Caspian Sea some few days after the recent escalation between Azerbaijan and Iran over border crossing that caused increased tensions between the two neighboring states.

\section{Pakistan and Azerbaijan}

The Nagorno-Karabakh region is internationally recognized as part of Azerbaijan, but Armenia occupies seven of its districts. Relations between Armenia and Pakistan deteriorated further in late 2016 when Armenia vetoed Pakistan's request as an observer in the Parliamentary Assembly of the Russian-led Collective Security Treaty Organization (CSTO). Thus Azerbaijan and Pakistan became closer. Pakistan was one of the first countries to recognize Azerbaijan as an independent state. Pakistan fully supported Azerbaijan's position on the issue of NagornoKarabakh at the United Nations. The case of Nagorno-Karabakh is similar to that of Kashmir. When the Soviet Union collapsed and Azerbaijan gained independence, its province of Nagorno-Karabakh was forcibly occupied by Armenia. Since then, the two countries have been fighting, sometimes intensifying and sometimes slowing down. Like Kashmir, the population of Nagorno-Karabakh is Muslim, and the Armenian army brutally tortured it and forced the locals to emigrate. Thousands of Muslims were martyred, including women and children. The sanctity of mosques was violated. Azerbaijan is constantly at war with Armenia for the people of Nagorno Karabakh. Just as Pakistan is in a constant state of war with India for Kashmiris.

The people in Azerbaijan love Pakistan very much and that is why the mutual cooperation between the two countries is constantly increasing. It seems on social media that the flag of Pakistan is flying in Azerbaijan everywhere. It is looking like Pakistan, Azerbaijan and Turkey have a defense agreement. The three countries announced that they will buy arms from each other. There will be an exchange of intelligence with each other. There will be military training and they will be together in all kinds of defense and practical matters. Cooperation among them in all fields is becoming stronger and deeper. The main reason for the propaganda against Pakistan, Azerbaijan, and Turkey close working is only that the three nations are united on issues of common interest including the support of the people of Jammu and Kashmir and Azerbaijan, like Turkey, is raising its voice for the rights of the Kashmiri Muslim brothers. Turkey has bought fighter jets from Pakistan. Azerbaijan plans to buy planes and other weapons. Pakistan is about to buy modern tanks from Turkey.

The three countries have also signed agreements on co-operation in the field of business and tourism. Cooperation is also underway with the COVID 19 vaccine. 
Direct flights between Islamabad and Baku are set to improve. A broader plan has been drawn up for the broader relations between the people of the three countries. Cooperation has also begun in the field of education. The construction of roads and railways is also under consideration. Iran has a claim that "Three Brothers Drills" or Pakistan, Azerbaijan, and Turkey's trilateral drill breached the international conventions on the Legal Status of the Caspian Sea agreed in 2018, which states that armed forces from nations other than Azerbaijan, Iran, Turkmenistan, Kazakhstan, and Russian are prohibited from having a presence in the Caspian Sea. The agreement, however, has yet to take effect since Iran has yet to sign it (Hunter, 2021).

\section{Indian Factor in NSTC (North South Transport Corridor)}

Russia and India are the two main funders and signatories to the NSTC project and they are for different reasons, outspokenly pro-Armenia that is providing Azerbaijan to incline towards Pakistan. Iran has influenced the other partners to exclude Azerbaijan from the NSIT corridor that has more to do with Azerbaijan's worsening bilateral relationship. Along with India, Iran, Azerbaijan, Russia, Kazakhstan, Turkey, Ukraine, and Belarus, Armenia is a member of this initiative. Meanwhile, Iran contributed more than others to the creation of the NSTC project that has the potential to become an international transport corridor that will run from Russia to Iran via Azerbaijan and connect by water with India (Chuhdhary, 2017). The corridor's construction would be endangered if there was a severe dispute between Iran with Azerbaijan. After the "Three Brothers Drill" in September 2021 Iran has announced that it has dropped Azerbaijan from the NSTC (North-South Transport Corridor) project, which will now connect Russia and other Eastern European countries with India via Armenia (Azerbaijani Geopolitics Sees the INSTC Reconnect with Armenia, 2021). This corridor has specific meanings for Pakistan and India relations in the context of CPEC.

\section{Azerbaijan Counter strategy of 'Zangezur Corridor}

The "Zangezur Corridor," as it has been dubbed, would construct a land route between Azerbaijan's Nakhichevan exclave on Armenia's west and mainland Azerbaijan on Armenia's eastern border. Tactically, this will enable Turkey that is a close ally and ethnolinguistic relative of Azerbaijani people to enlarge its economic reach and political support through an uninterrupted view of the land route that runs from Eastern Thrace, across the Caspian Sea, and into its native homelands of Central Asia, which border China. This development would essentially establish the groundwork for Turkey's long-awaited Turanian kingdom. Syunik is the southern region of Armenia which the Azerbaijani people name Zangezur, and it however is a very important area for Iran and Azerbaijan trade. It separates mainland Azerbaijan from its isolated exclave, the Nakhchivan, by Syunik a strategically vital region of Armenia. Both the leadership of Armenia and Azerbaijan are trying to normalize 
relations after the war in Nagorno Karabakh. Turkey is playing an important role as it is just a matter of time that Turkey will construct a land corridor connecting Azerbaijan not only to Nakhchivan but also to Turkey. The Nakhchivan corridor, which would circumvent Iran, would become part of a worldwide commerce route connecting China and Europe via the Caspian Sea (Rahimov, 2021).

In a joint press conference with President Aliyev, President Erdogan claims the Zenzegur corridor will connect the world for trade and logistic activities. The acquisition of the Zangezur Corridor provides Turkey with equal, if not greater, economic and geopolitical advantages. President Xi Jinping of China announced the inauguration of China's Silk Road in 2013, a fresh new double commercial corridor aimed at reopening links between China and its Western neighbors, including the Middle East, Europe, and Central Asia. The fact that the Silk Road is meant to pass via Turkey on its way to Europe while bypassing Armenia makes this project, also known as the China-led Belt and Road Initiative (BRI), important to understanding the Zangezur Corridor dispute. Avoiding Armenia becomes a key strategic advantage for China's compatriots. China and India are Asia's primary rivals, as is well known on a political level (Escobar, 2021).

Within this complex geopolitical context, China, Pakistan, and Pakistan's close ally, Turkey, as well as Azerbaijan, have formed an unbreakable bond against India and Iran's opposing interests. These partnerships are real and relevant within the context of the greater economic realities given by the silk route, even if they are not particularly antagonistic, as in China-Iran relations. To counteract the consequences of the Silk Road, India is developing its own economic trade route in order to avoid isolation and compete with China. India's intended route to the European market must, by consequence, avoid nations that support China's plan, notably, and most importantly in the context of the Zangezur conflict, Turkey and Azerbaijan, which are staunch partners and political and ideological allies of India's longtime foe, Pakistan. Because of the political divisiveness, India's only choice is to export its goods to Iran via the Arabian Sea and the Persian Gulf. The items will next travel by land through Iran, crossing the Armenian border at Zangezur, which is the sole safe route to the Black Sea ports of Georgia, where they will be delivered to European coasts. To stop India from using Iran as a transportation hub, Turkey has sought to control the economic trade routes to Europe by capturing the Zangezur Corridor through Azerbaijan. Turkey and Azerbaijan, have nearly entirely encircled Armenia by conquering the corridor, leaving the border of an unreliable neutral Georgia as the only access to the sea. The most important aspect of the process is that Iran does not want an alternate route to open in terms of transportation and energy corridors. To put it another way, the fundamental goal of the activities of Iran is to prevent the Zangezur Corridor from being built. Iranian General Kyumers Haydari said that they would not allow Iranian northwest frontiers to shift ("News Analysis: Why Iran launches military drill in NW borders?", 2021). So it become clear that 
blocking the Zangezur Corridor was one of the key reasons for Iran's activities against Azerbaijan.

\section{Conclusion}

Azerbaijan, Pakistan and Turkey's foreign ministers has seen each assist Azerbaijan in the Nagorno-Karabakh conflict and perform cooperative military drills, including near the Iranian border in September 2021. Azerbaijan, encouraged by its capture of much of Nagorno-Karabakh, has stated that it considers to be a sovereign enough to retake its territories and secure its interests. The alliance of Azerbaijan, Turkey, and Pakistan has broader consequences, with each committing to backing the territorial claims of the other in Armenia, Iran, Cyprus, and Kashmir, all of which are possibly unresolved. Azerbaijan interpreted Iran trade through NagornoKarabakh and left the idea to be part of INSTC. It has started to construct Zangezur corridor that can become a problem for Iran because it has the potential to cut down the importance and feasibility of INSTC sponsored by Iran and India. So it can be assumed that the construction of the Zangezur corridor is in the interests of Pakistan because it can become an extension of OBORI and connect with CPEC. Furthermore, Iran demonstrated that Shia Islam, on which it bases its own identity, is merely a foreign policy tool. Because the threat of war from Iran to Baku, a predominantly Shiite Nation, has proven that both sectarianism and Islamic brotherhood remain in idealism, not in practice. It can be noted that Iran considers the development of Caucasus-centered cooperative procedures to be counterproductive to its interests, and it is concerned about Pakistan, Turkey, and Azerbaijan's growing influence in the region. As a result, in the current context, when normalization processes on the Turkey-Azerbaijan-Armenia line are being debated, it has taken an aggressive stance toward Azerbaijan. In the context of Azerbaijan and Iran tension, Pakistan must have to work on such policy that can work in such a way that what Pakistan has gained in Caucasus region can be sustained and relations with Iran will not disturb. 


\section{References}

Aliyev, J. (2021, October 16). Armenia colluded with Iran on drug trafficking to Europe for 30 years: Azerbaijan president. https://www.aa.com.tr/en/world/armeniacolluded-with-iran-on-drug-trafficking-to-europe-for-30-years-azerbaijanpresident/2393702

Amirabdollahian, (2021, September 30). Iran does not tolerate Zionist regime's presence near its borders. https://en.irna.ir/news/84489498/Amirabdollahian-Iran-doesnot-tolerate-Zionist-regime-s-presence

Chuhdhary, D. R. (2017, December 05). INSTC to be operationalised mid-Jan 2018; game changer for India's Eurasia policy. https://economictimes.indiatimes.com/news/economy/foreign-trade/instcto-be-operationalised-mid-jan-2018-game-changer-for-indias-eurasiapolicy/articleshow/61926321.cms?from $=\mathrm{mdr}$

Club, A. N. (2021, September 21). The chairman of the Democratic Party of Azerbaijan, Sardar Jalaloglu, commenting on \#Iran's military exercises along the Araz: I can honestly say that such behavior is meaningless. As soon as Iran takes any action against us, \#Pakistani troops will most likely be in \#Tehran. 1/5 pic.twitter.com/9dt5WOG0jS.https://twitter.com/ajnewsclub/status/14404142 28897173512

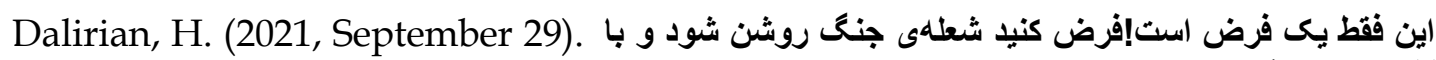

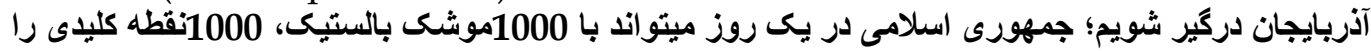

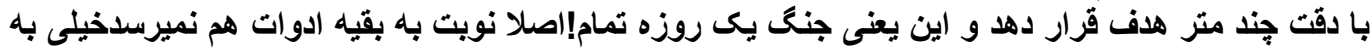
pic.twitter.com/bAVlG7cAiW. Retrieved October 25, 2021, from https:/ / twitter.com/HosseinDalirian/status/1443225884207587330

Escobar, P. (2021, October 07). The Iran-Azerbaijan Standoff Is a Contest for the Region's Transportation Corridors. https://www.strategicculture.org/news/2021/10/07/the-iran-azerbaijan-standoff-is-a-contest-for-theregions-transportation-corridors/

Esfandiari, G. (2021, October 01). Explainer: What's Behind Fresh Tensions On The IranAzerbaijan Border? https://www.rferl.org/a/iran-azerbaijan-military-drillsborder/31488035.html

Harel, A. (2021, September 03). 'Death by a thousand cuts': The U.S.-Israeli strategy if Iran nuke deal goes unsigned. https://www.haaretz.com/israelnews/.premium.HIGHLIGHT-death-by-a-thousand-cuts-the-u-s-israelistrategy-if-iran-nuke-deal-unsigned-1.10177440 
Hunter, S. T. (2021, October 09). Iran-Azerbaijan: What is behind the recent tensions? https://www.middleeasteye.net/news/iran-azerbaijan-tensions-explained

Iran says military exercises near Azeri border an issue of 'sovereignty'. (2021, September 28). https://english.alarabiya.net/News/world/2021/09/28/Iransays-military-exercises-near-Azeri-border-an-issue-of-sovereignty

Iranian Governor Assaulted During Inauguration Ceremony. (2021, October 23). https://www.eurasiareview.com/24102021-iranian-governor-assaulted-duringinauguration-ceremony/

Isayev, H., \& Mejlumyan, A. (2021, September 14). Azerbaijan starts charging Iranian trucks supplying Armenia. https://eurasianet.org/azerbaijan-starts-chargingiranian-trucks-supplying-armenia

Isayev, H., \& Mejlumyan, A. (2021, September 14). Azerbaijan starts charging Iranian trucks supplying Armenia. https://eurasianet.org/azerbaijan-starts-chargingiranian-trucks-supplying-armenia

Khan, I., \& Haider, S. K. (2021). Pakistan Relations with Azerbaijan in 21st Century. Pakistan Social Sciences Review, 5(I), 676-679. doi:10.35484/pssr.2021(5i) 50 Lindenstrauss, G., \& Celniker, I. (2012). Azerbaijan and Iran: Mutual Hostility but Limited Rivalry. Institute for National Security Studies. http:// www.jstor.org/stable/ resrep08233

Mikovic, N. (2021, October 28). Tensions with Azerbaijan reveal Iran's loss of influence in Caucasus: Nikola Mikovic. https://www.thearabweekly.com/tensions-azerbaijanreveal-irans-loss-influence-caucasus

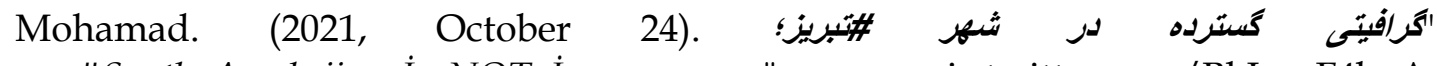
\#South_Azarbaijan_İs_NOT_Iran_ " pic.twitter.com/BkJmnF4bvA. https://twitter.com/bdb213c7da9b46f/status/1452356219197349898

Motamedi, M. (2021, October 01). Iran army holds drill near Azerbaijan border amid tensions. https://www.aljazeera.com/news/2021/10/1/iran-army-holds-drillnear-azerbaijan-border-amid-tensions

News Analysis: Why Iran launches military drill in NW borders? (2021, October 01). http://www.news.cn/english/2021-10/01/c_1310222071.htm

No Place for Israel in Iran's Neighboring Countries: IRGC General - Politics news. (2021, September 30). https:// www.tasnimnews.com/en/news/2021/09/30/2581490/no-place-forisrael-in-iran-s-neighboring-countries-irgc-general 
Oxford Analytica (2021), "Iran faces multiple challenges in managing Azerbaijan", Expert Briefings.

Rad, D. (2021, September 20). Azerbaijani, Turkish and Pakistani war games appear to prompt Iran to move infantry to border. https:/ / www.intellinews.com/azerbaijaniturkish-and-pakistani-war-games-appear-to-prompt-iran-to-move-infantry-toborder-221245/

Rahimov, R. (2021, June 06). Zangezur corridor to provide new link between Turkey, Azerbaijan.https://www.aa.com.tr/en/economy/zangezur-corridor-to-providenew-link-between-turkey-azerbaijan/2260088

Shahbazov, F. (2021, June 23). Shusha Declaration Cements Azerbaijani-Turkish Alliance. https://jamestown.org/program/shusha-declaration-cements-azerbaijaniturkish-alliance/

Sinaee, M. (2021, October 16). Iran, Armenia Reject Azerbaijani Drug-Smuggling Accusations. https://www.iranintl.com/en/20211016713392

Sofuoglu, M. (2021, October 01). Why is Iran deploying troops on its border with Azerbaijan? https://www.trtworld.com/magazine/why-is-iran-deployingtroops-on-its-border-with-azerbaijan-50377

'Three Brothers (2021)' Pakistan, Turkey, Azerbaijan joint military drills conclude: Dope Desi. https://dopedesi.com/2021/09/23/three-brothers-2021-pakistanturkey-azerbaijan-joint-military-drills-conclude/ 